\title{
Research Article: Influence of Bemisia tabaci Gennadiu on Bt cotton ecosystem in Marathwada region of Maharashtra
}

\section{A.G. BADGUJAR, B.V. BHEDE AND P.R. ZANWAR}

Article Chronicle: Received :

11.07.2017;

Accepted :

26.07.2017

KEY WoRds:

Bt cotton, Ecosystem,

Political status

Author for correspondence :

A.G. BADGUJAR

Department of

Agricultural

Entomology, Vasantrao

Naik Marathwada Krishi

Vidyapeeth, PARBHANI

(M.S.) INDIA

Email:anantbadgujar@

gmail.com

See end of the article for

authors' affiliations
SUMMARY : The severity whitefly is becoming a major concern to transgenic cotton farmers. Keeping this in view scientific survey of white fly (Bemisia tabaci Gennadius) incidence on Bt cotton was carried out from last five years (2009-10 to 2013-14), in six major cotton growing districts (viz. Parbhani, Hingoli, Nanded, Jalna, Aurangabad \& Beed) in Marathwada region of Maharashtra under Crop Pest Surveillance and Advisory Project (CROPSAP) by using ICT tools and total 171 ETL based advisories were issued twice in a week to monitor the pest. On the basis of taluka wise roving survey, the district wise mean data represented in Table 7 and stated that during 2009-10, maximum whitefly (per 3 leaves) incidence was recorded in Hingoli (5.92) followed by Jalna (5.20) and minimum in Beed (1.40) district. Similarly during 2010-11, the population was highest in Hingoli (8.72) followed by Jalna (7.72) and lowest in Beed (1.36). During 2011-12, it was more in Hingoli district (4.20) followed by Nanded (3.48) and minimum in Beed (0.76). During 2012-13, Hingoli district was severely infested by whiteflies (5.52) followed by Jalna (4.84). Whereas during 2013-14, Jalna district recorded highest population of whitefly (6.52) followed by Hingoli (5.44) and Parbhani (4.00). On the basis of five years survey data, the severity of whiteflies incidence was more during 2010-11. It was minimum during 2011-12, whereas similar trend of whitefly population was recorded in the years 2009-10, 2012-13 and 2013-14. It was further concluded that Hingoli and Jalna districts of Marathwada were identified as hotspots for whiteflies.

How to cite this article : Badgujar, A.G., Bhede, B.V. and Zanwar, P.R. (2017). Influence of Bemisia tabaci Gennadiu on Bt cotton ecosystem in Marathwada region of Maharashtra. Agric. Update, 12(TECHSEAR-1) : 259-264; DOI: 10.15740/HAS/AU/12.TECHSEAR(1)2017/259-264. 